\title{
Pelaksanaan Perjanjian Jual Beli Beras Antara Petani dengan Perum Dolog di Kabupaten Tanjung Jabung Barat
}

\author{
Nur Fauzia ${ }^{1}$ \\ Fakultas Hukum, Universitas Batanghari, Jalan Slamet Riyadi Broni Kota Jambi \\ (0741) 65351 \\ nurfauziaroni63@gmail.com
}

\begin{abstract}
Abstrak
Guna terlaksananya program pemerintah dan terangkatnya taraf hidup petani, maka Perum Dolog melakukan pembelian beras petani dengan harga yang memadai dan tidak merugikan petani itu sendiri. Secara yuridis, jual beli beras merupakan suatu kesatuan perbuatan, yang dapat disebut perbuatan hukum. Dikatakan demikian, karena dengan adanya jual beli beras tersebut menimbulkan hubungan hukum (perikatan) antara penjual (petani) dengan pembeli (Perum Dolog). Diantara perjanjian jual beli beras antara petani dengan Perum Dolog, juga terjadi di kabupaten Tanjung Jabung Barat, dimana para petani melakukan penjualan berasnya kepada Perum Dolog kabupaten Tanjung Jabung Barat. Dalam prakteknya perjanjian jual beli beras antara petani dengan Perum Dolog, Tanjung Jabung Barat ada terjadi wanprestasi yang dilakukan oleh pihak penjual, dimana pihak penjual terlambat melakukan pengiriman beras kepada pihak pembeli, padahal jatuh tempo pengiriman beras sesuai dengan isi perjanjian telah lewat waktu dan ada pula wanprestasi yang dilakukan oleh pihak pembeli, dimana pembeli terlambat dalam pembayarannya. Adanya wanprestasi yang terjadi tidak tertutup kemungkinan dengan adanya kendala-kendala yang dihadapi dalam pelaksanaan perjanjian jual beli beras itu sendiri.
\end{abstract}

Kata kunci: Perjanjian, jual beli beras, Perum Dolog

\begin{abstract}
To the implementation of the Government program and the terangkatnya farmers ' livelihood, then Perum Dolog rice farmers making a purchase price that is adequate and not detrimental to the farmers themselves. Legally, buy sell rice is a unity of works which can be called the deeds of the law. It is said so, because with the buy sell the rice poses a legal relationship (the Alliance) between the seller (the farmer) and buyer (Perum Dolog). Among the sale and purchase agreement between rice farmers with Perum Dolog, also occur in the West, where the Jabung Cape farmers selling berasnya to Tanjung Jabung Regency Dolog Perum West. In practice, the purchase agreement between rice farmers with Perum Dolog, Tanjung Jabung Barat there happens a tort committed by the seller, which the seller's late delivery of rice to the buyer, even though the maturity Rice deliveries in accordance with the contents of the agreement has been passing time and there is also a tort committed by the purchaser, where the buyer is late in payment. The existence of the tort that occurs is not a possibility with the constraints faced in the implementation of the agreement and selling the rice itself.
\end{abstract}

Keywords: agreements, buying and selling rice, Perum Dolog

${ }^{1}$ Dosen Fakultas Hukum Universitas Batanghari 


\section{PENDAHULUAN}

Perjanjian penyaluran beras tidak diatur dalam Kitab Undang-Undang Hukum Perdata, namun perjanjian itu dapat dibenarkan sesuai dengan asas kebebasan berkontrak dan beritikad baik sebagaimana tertuang dalam Pasal 1338 Kitab Undang-undang Hukum Perdata, yaitu :

Semua perjanjian yang dibuat secara sah berlaku sebagai undang-undang bagi mereka yang membuatnya.

Suatu perjanjian tidak dapat ditarik kembali selain dengan sepakat kedua belah pihak, atau karena alasan-alasan yang oleh undang-undang dinyatakan cukup untuk itu.

Suatu perjanjian harus dilaksanakan dengan itikad baik.

Perum Dolog selain bertugas melakukan penyaluran beras, juga berperan dalam pembelian beras. Dalam hal penyaluran dan pembelian beras tersebut diadakan suatu perjanjian jual beli.

Salah satu pasar pembelian beras oleh Perum Dolog adalah dari para petani di wilayah maupun di luar wilayah kerjanya. Dikarenakan pembelian beras yang dilakukan oleh Perum Dolog itu rutin sifatnya, maka untuk adanya suatu ikatan dan kepastian hukum, diadakanlah suatu perjanjian jual beli.

Meskipun Perum Dolog berhak dalam pengadaan perjanjian jual beli beras, tetapi tetap harus mendasarkan ketentuan syarat sahnya suatu perjanjian sebagaimana tertuang dalam Pasal 1320 Kitab Undang-undang Hukum Perdata yang menentukan:

Untuk sahnya suatu perjanjian diperlukan empat syarat:

1. Sepakat mereka yang mengikatkan dirinya;

2. Kecakapan untuk membuat suatu perikatan;

3. Suatu hal tertentu;

4. Suatu sebab yang halal.

Adanya ketentuan syarat sahnya perjanjian tersebut, karena tidak semua orang cakap berbuat hokum sebagaimana ditentukan dalam Pasal 1330 Kitab Undang-undang Hukum Perdata, yang menyatakan:

Yang tak cakap untuk membuat perjanjian adalah:

1. Anak yang belum dewasa;

2. Orang yang ditaruh di bawah pengampuan;

3. Perempuan yang telah kawin dalam hal-hal yang ditentukan undang-undang, dan pada umumnya semua orang yang oleh undang-undang dilarang untuk membuat perjanjian tertentu.

Adapun perjanjian jual beli itu menurut ketentuan Pasal 1457 Kitab Undang-undang Hukum Perdata adalah "suatu perjanjian, dengan mana pihak yang satu mengikatkan dirinya untuk menyerahkan suatu kebendaan, dan pihak yang lain untuk membayar harga yang telah dijanjikan".

Sedangkan menurut R. Subekti perjanjian jual beli itu adalah "suatu perjanjian bertimbal balik dalam mana pihak yang satu (si penjual) berjanji untuk menyerahkan hak milik atas suatu barang, sedang pihak yang lainnya (si pembeli) berjanji untuk membayar harga yang terdiri atas sejumlah uang sebagai imbalan dari perolehan hak milik tersebut".

Dalam hal perjanjian jual beli beras ini, ada kalanya beras yang menjadi objek perjanjian belum tentu jumlahnya maupun belum ada wujudnya tetapi telah

${ }^{2}$ R. Subekti, Aneka Perjanjian, PT. Citra Aditya Bakti, Bandung, 1995, hal.1. 
diperjanjikan untuk dijual dan dibeli. Hal ini dapat dibenarkan sebagaimana digariskan dalam ketentuan Pasal 1333 dan Pasal 1334 Kitab Undang-undang Hukum Perdata, yang lebih jelasnya dapat disimak dari penjelasan R. Wirjono Prodjodikoro sebagai berikut :

Pasal 1333 BW menyebutkan suatu syarat lagi bagi benda agar dapat menjadi object suatu perjanjian, yaitu benda itu harus tertentu, paling sedikit tentang jenisnya. Jumlah benda itu tidak perlu ditentukan dahulu, asal saja kemudian dapat ditentukan. Misalnya seorang pedagang mempunyai beras dalam gudangnya dan berjanji menjual semua atau sebagian dari beras itu kepada orang lain dengan harga sekian rupiah sekilogramnya. Perjanjian ini diperbolehkan, oleh karena kemudian secara menimbang dapat ditentukan beberapa kilogram beras yang sebetulnya dijual.

Menurut Pasal 1334 ayat 1 BW barang-barang yang seketika belum ada (teekomstige zaken) dapat menjadi object suatu perjanjian. Istilah "belum ada" dapat berarti mutlak (absolut) seperti halnya orang menjual padinya yang baru akan ditanam dalam tahun depan. Juga dapat berarti tak mutlak (relatief) seperti halnya orang menjual sejumlah beras, yang sudah berwujud beras, tetapi waktu itu masih menjadi milik orang lain dan akan jatuh di tangan si penjual. ${ }^{3}$

Sebagai pembeli, sangat dimungkinkan Perum Dolog mengharapkan untuk mendapat harga yang semurah-murahnya guna dapat dijual kembali dengan harga yang setinggi-tingginya, tetapi dikarenakan Perum Dolog adalah instansi pemerintah, dia berkewajiban mengemban tugas mensejahterakan masyarakat Indonesia, dengan cara memberi perlindungan dan peningkatan taraf hidup petani dari pembelian berasnya dan juga memberikan kenyamanan dan bantuan kepada warga masyarakat golongan menengah ke bawah dari penjualan berasnya.

Selama ini banyak petani yang dirugikan, karena beras yang dijualnya sangatlah murah dibandingkan dengan biaya dan tenaga yang harus dikeluarkannya mulai dari penggarapan sawah hingga pemanenan hasil, sedangkan diketahui bahwa beras itu merupakan bahan makanan pokok masyarakat Indonesia. Kerugian petani ini dalam kenyataan terlihat dengan mahalnya harga jual beras di tengah-tengah masyarakat, yang tidak sebanding dengan harga jual yang dilakukan oleh petani itu sendiri kepada Perum Dolog.

Guna terlaksananya program pemerintah dan terangkatnya taraf hidup petani, maka Perum Dolog melakukan pembelian beras petani dengan harga yang memadai dan tidak merugikan petani itu sendiri.

Secara yuridis, jual beli beras merupakan suatu kesatuan perbuatan, yang dapat disebut perbuatan hukum. Dikatakan demikian, karena dengan adanya jual beli beras tersebut menimbulkan hubungan hukum (perikatan) antara penjual (petani) dengan pembeli (Perum Dolog).

Dengan terjadinya perjanjian antara kedua belah pihak, maka timbul hak dan kewajiban antara petani dengan Perum Dolog, dimana pihak pembeli berkewajiban untuk membayar harga beras sesuai dengan jumlah dan jenis berasnya kepada penjual, sedangkan pihak penjual berkewajiban untuk menyediakan beras tersebut sesuai dengan yang disepakati.

${ }^{3}$ R. Wirjono Prodjodikoro, Azas-azas Hukum Perjanjian, CV. Mandar Maju, Bandung, 2000, hal.21. 
Diantara perjanjian jual beli beras antara petani dengan Perum Dolog, juga terjadi di kabupaten Tanjung Jabung Barat, dimana para petani melakukan penjualan berasnya kepada Perum Dolog kabupaten Tanjung Jabung Barat.

Dengan ditentukan hak dan kewajiban masing-masing pihak dalam isi perjanjian jual beli beras tersebut, menyebabkan para pihak dibebankan untuk memenuhi masing-masing prestasinya sesuai dengan isi perjanjian yang telah mereka sepakati bersama.

Tetapi dalam prakteknya ada terjadi wanprestasi yang dilakukan oleh pihak penjual, dimana pihak penjual terlambat melakukan pengiriman beras kepada pihak pembeli, padahal jatuh tempo pengiriman beras sesuai dengan isi perjanjian telah lewat waktu dan ada pula wanprestasi yang dilakukan oleh pihak pembeli, dimana pembeli terlambat dalam pembayarannya. Jika terjadi hal yang demikian, lantas bagaimana jalan keluar yang ditempuh oleh kedua belah pihak untuk menyelesaikan masalah tersebut.

Adanya wanprestasi yang terjadi tidak tertutup kemungkinan dengan adanya kendala-kendala yang dihadapi dalam pelaksanaan perjanjian jual beli beras itu sendiri. Apabila kendala-kendala ini tidak segera diatasi, maka bukan tidak mungkin para pihak selain melanggar ketentuan perjanjian yang telah mereka sepakati bersama juga secara tidak langsung melanggar ketentuan perundangundangan yang berlaku berkenaan dengan suatu perjanjian.

\section{Perumusan Masalah}

1. Bagaimana pelaksanaan hak dan kewajiban para pihak dalam perjanjian jual beli beras antara petani dengan Perum Dolog di kabupaten Tanjung Jabung Barat?

2. Faktor-faktor apakah yang menyebabkan terjadinya wanprestasi dalam pelaksanaan hak dan kewajiban pada perjanjian jual beli beras antara petani dengan Perum Dolog di kabupaten Tanjung Jabung Barat tersebut?

\section{METODE PENELITIAN}

Menurut Sugiyono metode penelitian adalah cara ilmiah yang digunakan peneliti untuk mendapatkan data dengan tujuan dan kegunaan tertentu. ${ }^{4}$ Penelitian ini menggunakan pendekatan penelitian kualitatif. Penelitian kualitatif adalah penelitian yang menggunakan latar alamiah dengan maksud untuk memahami fenomena tentang apa yang dialami oleh subjek penelitian secara holistik (utuh), dengan mendeskripsikan data dalam bentuk kata-kata dan bahasa, dan dengan memanfaatkan berbagai metode alamiah. Hasil analisis data tersebut berupa pemaparan yang berkenaan dengan situasi yang sedang diteliti dan disajikan dalam bentuk uraian narasi.

\section{HASIL DAN PEMBAHASAN}

Pelaksanaan Hak Dan Kewajiban Para Pihak Dalam Perjanjian Jual Beli Beras Antara Petani Dengan Perum Dolog Di Kabupaten Tanjung Jabung Barat

Dikarenakan petani sangat banyak, sehingga sulit untuk membuat perjanjian masing-masingnya, maka guna dapat mempermudah menjadikan perjanjian itu tidak terlalu banyak, dihimpunlah para petani dalam suatu badan hukum. Pada perjanjian jual beli beras yang diadakan oleh Perum Dolog kabupaten Tanjung

${ }^{4}$ Sugiyono, Metodologi Penelitian Administratif, Bandung, Alfabeta, 2010, hlm. 1 
Jabung Barat dilakukan dengan para petani yang terhimpun dalam usaha penggilingan padi dengan nama Usaha Baru.

Telah terikatnya dalam suatu perjanjian jual beli beras sebagaimana tertuang dalam Surat Perjanjian Jual Beli Beras Nomor PJB-001/PJB/03/2009, maka masing-masing pihak tidak hanya menuntut haknya tetapi juga melaksanakan kewajibannya. Adapun kewajiban masing-masing pihak ini yaitu hak Perum Dolog adalah menerima beras sesuai dengan jumlah dan kualitas yang diminta, sedangkan kewajibannya adalah membayar sejumlah uang sesuai dengan yang telah ditentukan dalam perjanjian kepada pihak petani melalui perhimpunannya, Usaha Baru. Sedangkan hak petani adalah menerima pembayaran atas beras yang dijualnya. Kemudian kewajibannya adalah menyediakan dan menyerahkan sejumlah beras yang diminta oleh Perum Dolog kabupaten Tanjung Jabung Barat.

Mengenai pelaksanaan perjanjian jual beli beras yang diadakan, dapatlah disimak penjelasan sebagai berikut.

a. Mulainya Perjanjian

Perjanjian jual beli beras yang diadakan antara petani dengan Perum Dolog Tanjung Jabung Barat dimulai pada saat terjadinya kesepakatan yang diwujudkan dengan penanda tanganan surat perjanjian (Perjanjian Jual Beli Beras Nomor PJB-001/PJB/03/2009), pihak petani menyerahkan jaminan bank kepada pihak Perum Dolog seharga 1\% (satu) persen dari harga kontrak (Rp.230.000.000), yaitu Rp.2.300.000,- (dua juta tiga ratus ribu rupiah) serta menyediakan karung dan pihak Perum Dolog Tanjung Jabung Barat akan membayar sejumlah beras yang diterima dari pihak petani, atau tepatnya terhitung tanggal 12 Maret 2009 hingga paling lambat 30 Juni 2009.

b. Penyiapan Bahan

Bahan yang dimaksud adalah karung untuk pengisian beras yang disediakan oleh pihak Petani, dimana kriteria karungnya adalah :

1) Karung plastik baru dengan benang kuralon;

2) Ukuran karung $20 \mathrm{Kg}$.

c. Penyerahan Beras

Beras yang merupakan kewajiban petani diserahkan selama tahun pengadaan 2009 terhitung sejak penanda tanganan secara bertahap paling lambat 30 Juni 2009. Penyerahan beras dilakukan oleh pihak petani langsung ke gudang Perum Dolog Tanjung Jabung Barat.

d. Pembayaran

Dari penyerahan beras yang dilakukan oleh pihak petani dan diterima oleh pihak Perum Dolog Tanjung Jabung Barat, dengan ketentuan kualitas beras :

1) Kadar air

maksimum $14 \%$

2) Butir patah/broken

3) Derajat sosoh

maksimum $20 \%$

4) Butir menir maksimum $95 \%$ maksimum $2 \%$

Pihak Perum Dolog Tanjung Jabung Barat membayar harga beras tersebut dengan harga Rp.4.600,- (empat ribu enam ratus rupiah) per kilogramnya, yang keseluruhanya sebanyak $50.000 \mathrm{Kg}$ dengan harga Rp.230.000.000,- (dua ratus tiga puluh juta rupiah). Apabila pihak petani terlambat dalam pemenuhan jumlah beras yang diminta, maka terhadapnya dikenakan denda 1/1000 (satu per mil) dari sisa harga beras yang belum diserahkan per hari, tetapi apabila pihak petani tidak juga memenuhi 
kewajibannya, maka pihak Perum Dolog Tanjung Jabung Barat dapat mencairkan jaminan bank pihak petani dan/atau menuntut ganti kerugian kepada pihak petani.

Di samping itu dalam penyerahan beras, pihak petani harus mengeluarkan biaya untuk pengangkutan dan bongkar muat beras di gudang Perum Dolog Tanjung Jabung Barat. Dalam kenyataan, pihak petani sering melakukan keterlambatan dalam pemenuhan beras yang diminta oleh pihak Perum Dolog, sehingga selain bertentangan dengan ketentuan perjanjian, pihak petani mengalami kerugian dalam pembayaran.

e. Penyelesaian Perselisihan

Apabila terjadi perelisihan sebagaimana 2 (dua) kali kejadian pada Perum Dolog Tanjung Jabung Barat, maka langkah yang ditempuh adalah melakukan musyawarah untuk mendapatkan kesepakatan, tetapi apabila musyawarah ini tidak berhasil, maka langkah terakhir yang ditempuh adalah mengajukannya ke sidang Pengadilan Negeri Kuala Tungkal.

Dalam kenyataannya perselisihan diselesaikan hanya sampai tahap musyawarah antar pihak.

f. Berakhirnya Perjanjian

Perjanjian jual beli beras ini dilakukan para pihak dalam masa tiga bulan, tetapi penyerahan beras dan pembayaran pertiap satu bulan. Perjanjian jual beli beras ini dapat diperpanjang lagi untuk tiga bulan selanjutnya sesuai dengan kesepakatan para pihak.

Didasarkan hal tersebut di atas, diketahui bahwa pelaksanaan hak dan kewajiban para pihak dalam perjanjian jual beli beras antara petani dengan Perum Dolog Tanjung Jabung Barat telah sesuai dengan isi perjanjian sebagai undang-undang bagi mereka, walaupun ada sedikit ketidak sesuaian dalam hal terjadinya wanprestasi oleh pihak petani dalam penyerahan berasnya, maka akibat hukum yang timbul adalah petani dikenakan denda sebesar 1/1000 (satu per mil) dari harga beras yang terlambat diserahkan.

\section{Faktor-faktor Penyebab Terjadinya Wanprestasi}

Dalam pelaksanaan perjanjian jual beli beras antara petani dengan Perum Dolog Tanjung Jabung Barat memang ditemui adanya suatu wanprestasi terutama dari pihak petani berupa terlambat dalam penyerahan beras atau tidak terpenuhinya permintaan beras yang telah diperjanjikan. Adanya wanprestasi yang terjadi tersebut disebabkan oleh beberapa factor, yaitu berupa :

a. Faktor Alam

Hal ini tidaklah dapat diduga kejadianya ataupun kalau terjadi sulit untuk ditanggulangi. Kejadian dari faktor alam ini adalah berupa :

1) Banjir

Dengan terjadinya banjir yang merendam tanaman padi, walaupun satu hari akan mematikan tanaman padi tersebut sehingga padi yang direncanakan akan menghasilkan, tidak jadi dipanen atau kalaupun dapat dipanen, hasilnya sangatlah rendah, baik kualitas maupun kuantitasnya, yang apabila dijual harganya sangat rendah, yang tidak menutup biaya operasional dikeluarkan.

2) Kemarau

Pada musim kemarau tanah menjadi gersang dan kering, sehingga tanaman padi menjadi kering dan mati. Akibat kering dan matinya batang padi, maka 
panen gagal, sehingga tidak dapat menyerahkan padi yang diminta oleh pihak Perum Dolog kabupaten Tanjung Jabung Barat.

3) Hama

Hama disini adalah berupa serangga atau binatang, yang tiba-tiba menyerang padi, hingga hasil padi berkuang dan mengarah pada kurangnya penyerahan padi/beras yang ditentukan Perum Dolok kabupaten Tanjung Jabung Barat kepada petani.

b. Faktor Manusia

Hal ini adalah suatu perbuatan manusia yang mengakibatkan rusaknya ekosistem yang ada. Faktor manusia ini dapat berupa :

1) Keinginan untuk mendapatkan keuntungan

Sebagaimana diketahui bahwa dalam perjanjian yang diadakan, telah ditentukan harga dari beras tersebut sesuai dengan harga ketentuan pemerintah, apabila dijual kepada masyarakat umum harganya akan lebih tinggi, maka dari pada menjual ke Perum Dolog lebih baik menjual kepada masyarakat umum. Dengan keadaan ini, pihak petani kurang dalam penyerahan berasnya kepada Perum Dolog.

2) Kekurangan Dana Operasional

Sebagaimana bahwa pihak petani selain menyerahkan beras, juga harus mengeluarkan biaya operasional, yang diantaranya adalah biaya pengangkutan dan bongkar muat beras ke gudang Perum Dolog. Dikarenakan hasil panen sedikit sedangkan biaya operasional sama saja, maka pihak petani menunggu jumlah beras sudah cukup banyak baru diserahkan dan kadangkala menjelang banyak, beras tersebut dijual kepada masyarakat umum.

\section{SIMPULAN}

1. Pelaksanaan hak dan kewajiban para pihak dalam perjanjian jual beli beras yang diadakan antara petani dengan Perum Dolog kabupaten Tanjung Jabung Barat pada dasarnya telah sesuai dengan isi perjanjian yang mereka adakan, kecuali wanprestasi penyerahan beras yang dilakukan oleh pihak petani dengan akibat hukum si petani dikenakan denda sebesar 1/1000 (satu per mil) dari harga beras yang terlambat diserahkan.

2. Faktor penyebab terjadinya wanprestasi yang dilakukan oleh petani dalam pelaksanaan perjanjian jual beli beras dengan Perum Dolog di kabupaten Tanjung Jabung Barat adalah berupa :

a. Faktor alam, seperti :

1) Banjir

2) Kemarau panjang; dan

3) Hama.

b. Faktor manusia, seperti :

1) Keinginan untuk mendapatkan keuntungan yang besar;

2) Kekurangan dana operasional.

\section{DAFTAR PUSTAKA}

H.S. Salim. Hukum Kontrak Teori \& Teknik Penyusunan Kontrak, Sinar Grafika,Jakarta, 2006.

Muljadi, Kartini \& Widjaja, Gunawan. Perikatan Yang Lahir Dari Perjanjian, PT. Raja Grafindo Persada, Jakarta. 
Prodjodikoro, R. Wirjono. Azas-azas Hukum Perjanjian, CV. Mandar Maju, Bandung, 2000.

Subekti, R. Hukum Perjanjian, Intermasa, Jakarta, 2000. . Aneka Perjanjian, PT. Citra Aditya Bakti, Bandung, 2000.

Subekti, R. Dan Tjitrosudibio, R. Kitab Undang-undang Hukum Perdata, Pradnya Paramita, Jakarta, 2006.

Syahrani, H. Ridwan. Seluk Beluk Dan Asas-asas Hukum Perdata, Alumni, Bandung, 2004. 